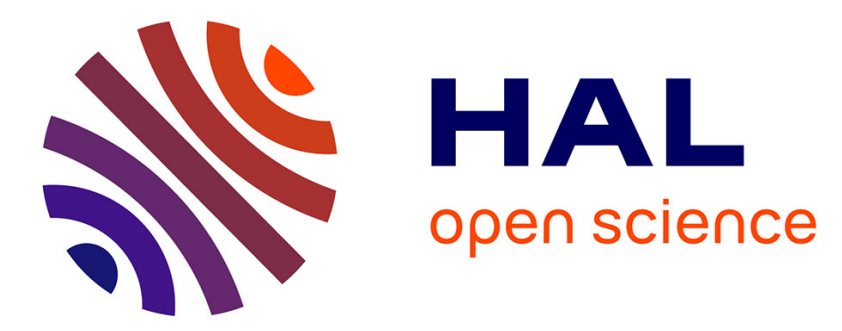

\title{
Controlled dissolution of quartz material.Part II. Quartz chemical etching applied to blanks industrial manufacturing
}

\author{
O. Cambon, M. Deleuze, J. Michel, J. Aubry, A. Goiffon, E. Philippot
}

\section{- To cite this version:}

O. Cambon, M. Deleuze, J. Michel, J. Aubry, A. Goiffon, et al.. Controlled dissolution of quartz material.Part II. Quartz chemical etching applied to blanks industrial manufacturing. Journal de Physique IV Proceedings, 1994, 04 (C2), pp.C2-85-C2-91. 10.1051/jp4:1994211 • jpa-00252479

HAL Id: jpa-00252479

https://hal.science/jpa-00252479

Submitted on 1 Jan 1994

HAL is a multi-disciplinary open access archive for the deposit and dissemination of scientific research documents, whether they are published or not. The documents may come from teaching and research institutions in France or abroad, or from public or private research centers.
L'archive ouverte pluridisciplinaire HAL, est destinée au dépôt et à la diffusion de documents scientifiques de niveau recherche, publiés ou non, émanant des établissements d'enseignement et de recherche français ou étrangers, des laboratoires publics ou privés. 


\title{
Controlled dissolution of quartz material. Part II. Quartz chemical etching applied to blanks industrial manufacturing
}

\author{
O. CAMBON, M. DELEUZE, J.P. MICHEL, J.P. AUBRY, A. GOIFFON* and E. PHILIPPOT*
}

CEPE, 44 Avenue de la Glacière, BP. 165, 95105 Argenteuil cedex, France

* UMII - LPMS, Place Eugène Bataillon, 34095 Montpellier cedex 5, France

\begin{abstract}
In many electronic applications, chemical etching process is used to manufacture the substrates. This method has been applied for long on quartz crystal blanks manufacturing for minor adjustments of the vibration frequencies.

This paper pesents a way to implement an industrial chemical etching process specially dedicated for large thickness removals without damaging the blanks surface texture. It will be shown how were defined the choice of the etching solvent, and the most sensitive parameters. An industrial equipement will be presented whose principle was deduced from the sensitivity study of these parameters. Finally, the electrical performances of the resonators processed on this equipment will be compared with the performances achieved by conventionnal means.
\end{abstract}

\section{INTRODUCTION}

Chemical etching can bring numerous advantages on the manufacturing of quartz plates: -The plate surface stresses produced by mechanical grinding and lapping are removed.

-This process is compatible with a collective and automatic treatment of blanks.

-Moreover, if the chemical etching does not damage the surface texture, it is possible to manufacture high frequency resonators starting from usual mechanically lapped plates.

-Finally, if this process is able to improve the surface texture of the ground plates, it is possible to suppress some lapping steps. process.

All these points are favourable to a plate manufacturing by industrial chemical etching

For long, a lot of works $[1,6]$ have been published on quartz chemical etching in fluoride media. But these solutions tend to damage the surface texture for large thickness removals. The studies [7] have shown that the sodium hydroxide solutions could solve the surface texture problem [8]. These results were widely promizing and allowed to envisage the industrialisation of this process.

This paper concerns the principal results of the study exhibiting the most influential experimental parameters which must be strictly controlled during the etching. Then, the industrial development is presented with piezoelectric results. 


\section{STUDY RESULTS}

\subsection{Quartz solvent}

Fluoride media are the well known solvent of the silica. Concerning the quartz, these solutions are used to manufacture crystal blanks only for fine adjustments of vibration frequencies.

Knowing that crystal growth and dissolution are governed by the same thermodynamic relations $[9,11]$, sodium hydroxide, a quartz crystal growth solvent, has been chosen in the aim to palliate surface damaging during etching. To obtain important etching rates at atmospheric pressure, the first tests demonstrated that sodium hydroxide concentration must be high. $\mathrm{NaOH}-\mathrm{H}_{2} \mathrm{O}$ phase diagram shows a congruent mixture with a melting point at $65^{\circ} \mathrm{C}$ for a ponderal composition of $69 \%$ of sodium hydroxide corresponding to the formula $\mathrm{NaOH}, \mathrm{H}_{2} \mathrm{O}$. Thus, a very concentrated solution can be obtained for low temperatures (from 100 to $200^{\circ} \mathrm{C}$ ).

\subsection{Influent Parameters}

Plate thicknesses and surface finish are the two essential characteristics achieving respectively the frequency resonance and the surtension of the resonators. These two characteristics are followed during the chemical etching process. Influent factors are reviewed in this paragraph.

\subsubsection{Kinetics}

Figures 1 and 2 present the etching rate $\mathrm{R}$ in $\mathrm{NaOH}, \mathrm{H}_{2} \mathrm{O}$ solvent versus temperature respectively for the AT and SC cuts and for different quartz quantities dissolved concentrations.

\section{a. Etching temperature}

In all cases, curves present an exponential behaviour showing that quartz dissolution is a thermally activated Arrhenius reaction. The values of the activation energy are the same for the two orientations $\left(E a=87.9 \mathrm{~kJ}^{\star} \mathrm{mol}^{-1}\right)$, that is to say that the chemical dissolution mechanism is identical in the two cases. This mechanism is based on an electron motion along the Si-O link widely described by PRIGOGINE and al $[12,13]$

Etching temperature must be tightly controlled to ensure a given etching rate during the process. Figure 3 presents the theoretical influency of the temperature precision of the etching bath in terms of frequency adjustment precision (for three etching depths: 10, 20, $30 \mu \mathrm{m}$ and for three temperatures: $160,170,180^{\circ} \mathrm{C}$ ). Knowing that the required frequency precision is of several hundredths $\mathrm{F}^{2}$, it is important to evaluate the admissible temperature error to manufacture the plates. Thus, if the variation of the etching bath temperature is higher than $0.1^{\circ} \mathrm{C}$ it is essential to measure contineously the temperature during the chemical etching to take this variation into account.

\section{b. Plate orientation influency}

The mathematic formula of these curves shows that the plate orientation is an influent parameter for the kinetic: the etching rate is about 3.5\% greater for the AT cut than far the SC one. This behaviour is due to the quartz crystalline structure for which the AT plane is more reactive than the $\mathrm{SC}$ one. 


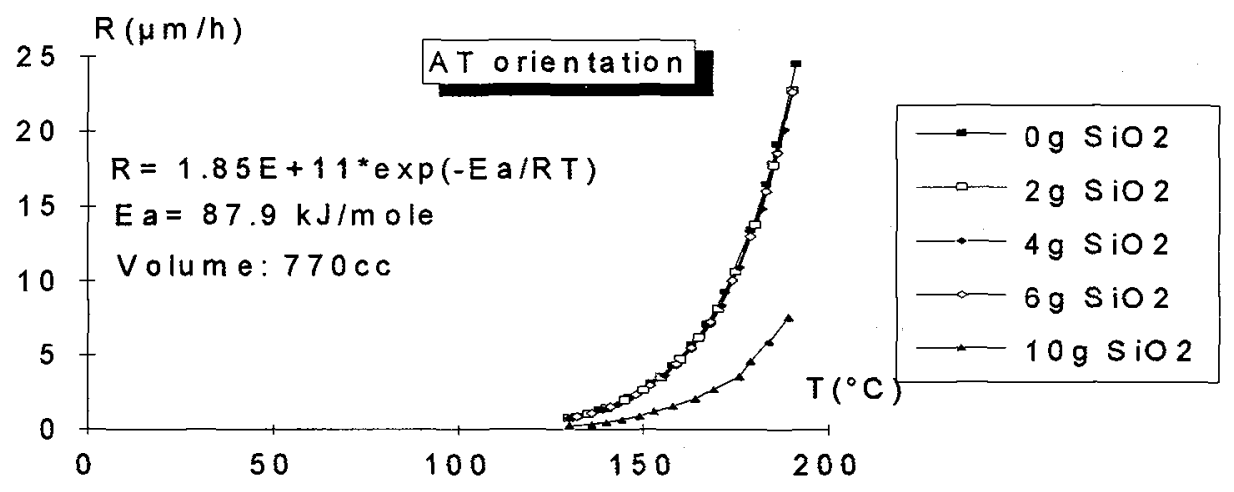

Figure 1: AT orientation dissolution kinetics

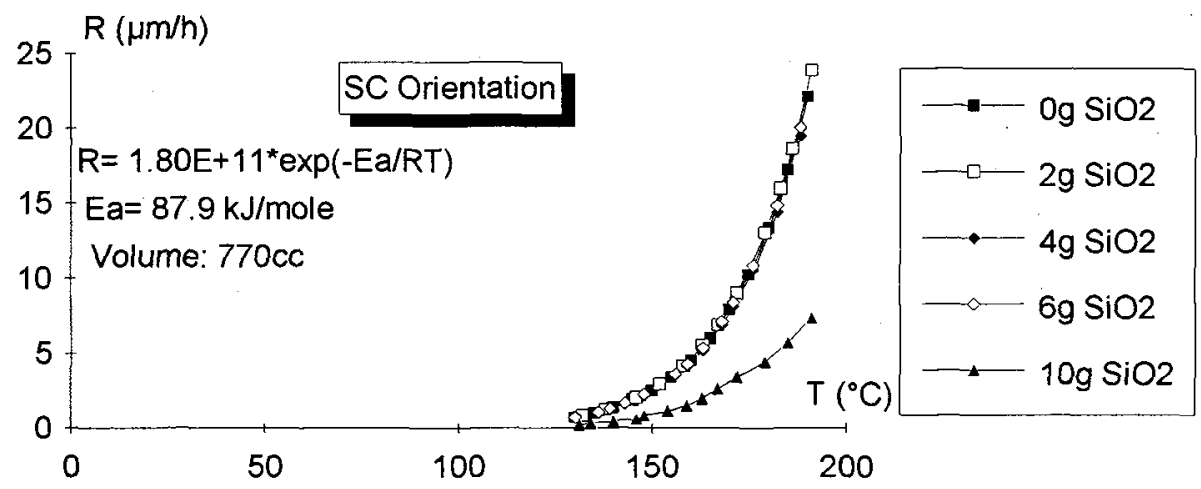

Figure 2: SC orientation dissolution kinetics

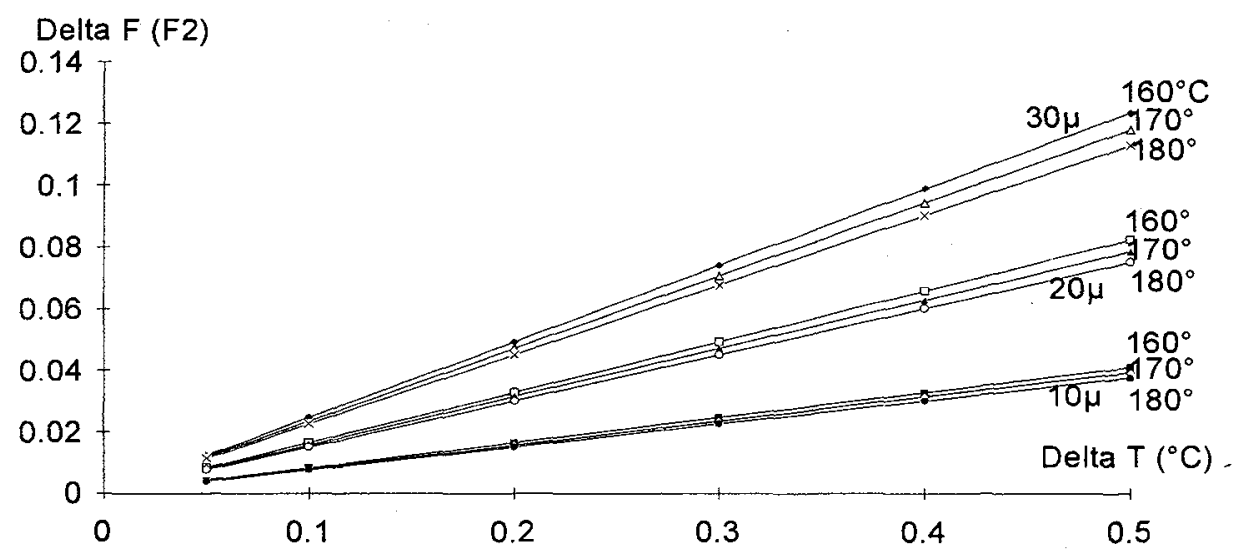

Figure 3: Calculation of the frequency adjustment precision due to the temperature variation for 3 etching depth values $(10,20,30 \mu \mathrm{m})$ and 3 temperature values (160, $\left.170,180^{\circ} \mathrm{C}\right)$. 
If the etching dissolution depends on the plate orientation, the plate orientation may vary during the etching of the substrates. It has been studied. The results presented in table I show that chemical etching does not modify the plate orientation even for large thickness removals.

\begin{tabular}{|c|c|c|c|c|}
\hline Orientation & Before etching & After etching & Etching depth & Measure error \\
\hline AT & $\theta=35^{\circ} 23^{\prime} 15^{\prime \prime}$ & $\theta=35^{\circ} 24^{\prime} 03^{\prime \prime}$ & $600 \mu \mathrm{m}$ & $\Delta \theta=+1-30^{\prime \prime}$ \\
\hline SC & $\theta=22^{\circ} 39^{\prime} 57^{\prime \prime}$ & $\theta=22^{\circ} 39^{\prime} 26^{\prime \prime}$ & $580 \mu \mathrm{m}$ & $\Delta \theta=+/-30^{\prime \prime}$ \\
\hline & $\varphi=34^{\circ} 03^{\prime} 20^{\prime \prime}$ & $\varphi=34^{\circ} 05^{\prime} 39^{\prime \prime}$ & & $\Delta \varphi=+1-3^{\prime}$ \\
\hline
\end{tabular}

\section{Table 1}

\section{c. $\mathrm{SiO}_{2}$ concentration}

To simulate the increase of $\mathrm{SiO}_{2}$ concentration during quartz dissolution and evaluate its influence on kinetics, solutions with different $\mathrm{SiO}_{2}$ concentrations were prepared and the kinetics curves were drawn. Figures 1 and 2 give the variation of the etching rate versus the dissolved $\mathrm{SiO}_{2}$ quantity. During the quartz etching, the $\mathrm{SiO}_{2}$ concentration of the solution increases while the etching rates tend to decrease. Indeed, when a crystal is immerged into a solvent it is dissolved until the solution reaches the saturation $\left(\mathrm{SiO}_{2}\right.$ concentration corresponding to the equilibrium between the solution and the crystal). In this case, the etching rate is zero. The curves show that the etching rate is constant and begins to decrease for a $\mathrm{SiO}_{2}$ concentration value of about $13 \mathrm{~g} \mathrm{SiO}_{2} / \mathrm{l}$. At this stage, the "etching potential" of the solution falls down.

The periodicity of the solution renewal is determined from these curves.

\section{d. $\mathrm{NaOH}$ concentration}

At the etching temperatures used (from 150 to $180^{\circ} \mathrm{C}$ ), the solution tends to evaporate. If the $\mathrm{H}_{2} \mathrm{O}$ vapours are not condensated, the $\mathrm{NaOH}$ concentration increases leading to a decrease of the etching rates. This behaviour has been verified by evaluation of the dissolution kinetics for different $\mathrm{NaOH}$ concentrations. [7]

Thus, $\mathrm{NaOH}$ concentration is an important parameter which must be strictly controlled during the process.

\section{e. Wafer carrier geometry}

The carriers must present simultaneously several properties:

- Resistance of the carrier material toward both temperature and chemical etching.

- Excellent solution flowing around the plates avoiding etching rate variations.

-The carrier does not produce any mark on the plate surface during the process.

-The carrier must be able to ensure an industrial use, with a high throughput.

\subsubsection{Surface texture}

The evolution of the surface texture during the chemical etching is evaluated by average roughness measurement $(\mathrm{Ra})$. This study has been performed on the AT and SC orientations for ground and polished plates. The results show that it is possible to use the $\mathrm{NaOH}, \mathrm{H}_{2} \mathrm{O}$ solvent as a polishing agent for AT but in the case of the SC orientation this solvent is not convenient to polish the initially ground plates [7, 14]. 


\section{INDUSTRIALISATION}

\subsection{Industrial equipment (figure 4)}

The equipment which has been developped for the industrial chemical etching has three main functions:

- Substrates cleaning before etching

- Chemical etching to adjust the resonator frequencies

- Final rinsing and drying.

The wafer carriers are filled up with quartz substrates and grouped by processing batches. A robotic and automatic manipulator conveys each batch into all the baths from the cleaning phase to the drying one.

The production capability of such an equipment can reach 3200 plates per one day.

\subsection{Chemical etching phase}

This phase consists of three steps

1- Heating of the wafers: To avoid thermal shocks, the wafers are heated at $180^{\circ} \mathrm{C}$. Moreover, through this step, the temperature of the etching solution is not modified while the batch is introduced in the tank.

2- Chemical etching: The table II summarizes the influency of the most important parameters which must be controlled during the process. This analysis lets one consider the equipment configuration, the control means and organization which have been adopted.

\begin{tabular}{|c|c|c|c|c|c|}
\hline Parameter & {$[\mathrm{NaOH}]$} & {$\left[\mathrm{SiO}_{2}\right]$} & Etching temperature & Plate orientation & Surface finish \\
\hline $\begin{array}{c}\text { Control } \\
\text { mean }\end{array}$ & $\begin{array}{c}\text { Vapour } \\
\text { condensation } \\
\text { system }\end{array}$ & $\begin{array}{c}\text { Solution } \\
\text { replacement } \\
\text { periodicity }\end{array}$ & $\begin{array}{c}\text { Control thermocouple } \\
\text { and monitoring system. } \\
\text { Homogeneity ensured } \\
\text { by a stirrer }\end{array}$ & $\begin{array}{c}\text { All plates in one } \\
\text { batch have the } \\
\text { same orientation }\end{array}$ & $\begin{array}{c}\text { All plates in one } \\
\text { batch have the } \\
\text { same surface } \\
\text { finish }\end{array}$ \\
\hline
\end{tabular}

Table II

The etching bath consists of two parts:

- a hot thermostated zone: the solution is heated until the etching temperature (from 160 to $190^{\circ} \mathrm{C}$ ) and the stability $\left(+/-0.5^{\circ} \mathrm{C}\right.$ ) is obtained through a thermostated oil bath, while a mechanical stirrer gives the temperature homogeneity $\left(+/-0.05^{\circ} \mathrm{C}\right)$. During the process, the temperature is measured by a thermocouple connected to a computer. Thus, the etching rate is contineously calculated taking into account the eventual temperature variations of the etching bath. The process is monitored from this programm.

- a vapour condensation zone: above the etching solution, the vapours are condensated by a streamer containing a cooling liquid which keeps the $\mathrm{NaOH}$ concentration constant even if the cover is open. A cooled cover with a safety valve closes the tank for the security.

3- Neutralization step: After chemical etching, substrates are immerged into an acid solution to neutralize the basic solvent. This step is controlled by a pHmeter adjusting automatically the $\mathrm{pH}$ value. 
To implement such an equipment, it is necessary to take into account the questions of security according to the industrial application concerning the solution preparation, the neutralization steps and the effluent.

\section{PIEZOELECTRIC RESULTS}

In this part, the manufacturing of different kinds of resonators by chemical etching process is reviewed. Table III summarizes the main results on the chemical frequency adjustments and the resonator performances in terms of $Q^{*} F$ values.

\begin{tabular}{|c|c|c|c|c|c|c|c|}
\hline \multicolumn{7}{|c|}{ CHEMICAL ETCHING ADJUSTMENT } & $\begin{array}{c}\text { Conventional } \\
\text { means }\end{array}$ \\
\hline Cut & $\begin{array}{c}\text { Initial } \\
\text { surface } \\
\text { texture }\end{array}$ & F (MHz) & $\begin{array}{c}\text { Vibration } \\
\text { mode }\end{array}$ & $\begin{array}{c}\text { Etching } \\
\text { depth }\end{array}$ & $\begin{array}{c}\text { Frequency } \\
\text { adjustment } \\
\text { precision }\end{array}$ & Q*Fr & Q*Fr \\
\hline AT & Ground & 4.098 & Fifth overtone & $13 \mu \mathrm{m}$ & $+/-0.05 \mathrm{kHz}$ & $8.40 \mathrm{E}+12$ & \\
\hline AT & Polished & 4.098 & Fifth overtone & $5 \mu \mathrm{m}$ & $+/-0.05 \mathrm{kHz}$ & $1.02 \mathrm{E}+13$ & $1 \mathrm{E}+13$ \\
\hline SC & Polished & 10 & $\begin{array}{c}\text { Third } \\
\text { overtone }\end{array}$ & $5 \mu \mathrm{m}$ & $+/-0.25 \mathrm{kHz}$ & $1.05 \mathrm{E}+13$ & $1 \mathrm{E}+13$ \\
\hline AT & Ground & 47 & Fundamental & $13 \mu \mathrm{m}$ & $+/-5 \mathrm{kHz}$ & $1.62 \mathrm{E}+12$ & $1.2 \mathrm{E}+12$ \\
\hline AT & Polished & 72 & Fundamental & $5 \mu \mathrm{m}$ & $+/-20 \mathrm{kHz}$ & $4.00 \mathrm{E}+12$ & $3.5 \mathrm{E}+12$ \\
\hline AT & Polished & 146.5 & Fundamental & $5 \mu \mathrm{m}$ & $+1-100 \mathrm{kHz}$ & $2.60 \mathrm{E}+12$ & $2 \mathrm{E}+12$ \\
\hline
\end{tabular}

Table III

Chemical etching of the ground plates is performed in two phases. During the first one, the superficial disturbed layer is removed and the surface texture is improved. The study has shown that the etching rate is not constant at the beginning of the etching of ground plates. During the second phase, the plate frequency is adjusted.

Concerning the frequency adjustment precision, chemical etching process is able to lead to better values than the ones reached by conventional manufacturing means.

As for electrical characterizations of the resonators, it is well known that the surtension $Q$ factor is widely influenced by the plate surface texture. Thus, table III gives the $Q^{\star} F$ values of plates adjusted by chemical etching process on one hand and by conventional means on the other hand. It can be seen that chemical etching process produces a surface finish even better than the one reached by the commonly used means.

In table III the three first resonators are used for oscillator applications requiring a very high frequency stability. The chemically adjusted resonators have been characterized on oscillator devices. The slope value of the relative frequency variation over one month reaches very good performances (few $10^{-9}$ thirty days after the measurement beginning).

\section{CONCLUSION}

This paper has related the various results which obtained during the quartz plate manufacturing by $\mathrm{NaOH}$ solution in accordance to previous works by PHILIPPOT and al. These results have demonstrated that the chemical etching process is suitable for an industrial implementation. The resonators manufactured by this process have demonstrated a high level of performance even higher than those obtained by mechanical means. 


\section{REFERENCES}

[1] K. BRAUER and E. MULLER, Cryst. Res. Technol. 19 (1984) K101.

[2] R. J. BRANDMAYR and J. R. VIG, 40th Annual Frequency Control Symposium (1986) 86.

[3] J. R. HUNT, 41st Annual Frequency Control Symposium (1987) 183.

[4] J. K. VONDELING, J. Mater. Sci. 18 (1983) 3621.

[5] C. R. TELLIER, Surf. Technol., 21 (1984) 83.

[6] J.C. BRICE, J. DOWSETT and E. D. FLETCHER, 35th Annual Frequency Control Symposium (1981) 312.

[7] M. DELEUZE, A. GOIFFON, A. IBANEZ, E. PHILIPPOT, 7th European Frequency and Time Forum (1993) 255.

[8] Patent $n^{\circ} 9109170$

[9] J. FRENKEL, J. Phys. USSR, 9 (1945) 392.

[10] W. K. BURTON, N. CABRERA, F.C. FRANK, Phil. Trans. Soc. London (1951) 243.

[11] W. G. JOHNSTON, Prog. Ceram. Sci., 2 (1962), 1.

[12] M. PRIGOGINE and J. FRIPIAT, J. Chimie Physique, 76 (1979) 26.

[13] H. BORN and M. PRIGOGINE, J. Chimie Physique, 76 (1979) 538.

[14] M. DELEUZE, O. CAMBON, A. GOIFFON, A. IBANEZ, E. PHILIPPOT, IEEE Int. Freq. Control Symp., (1993) 381.

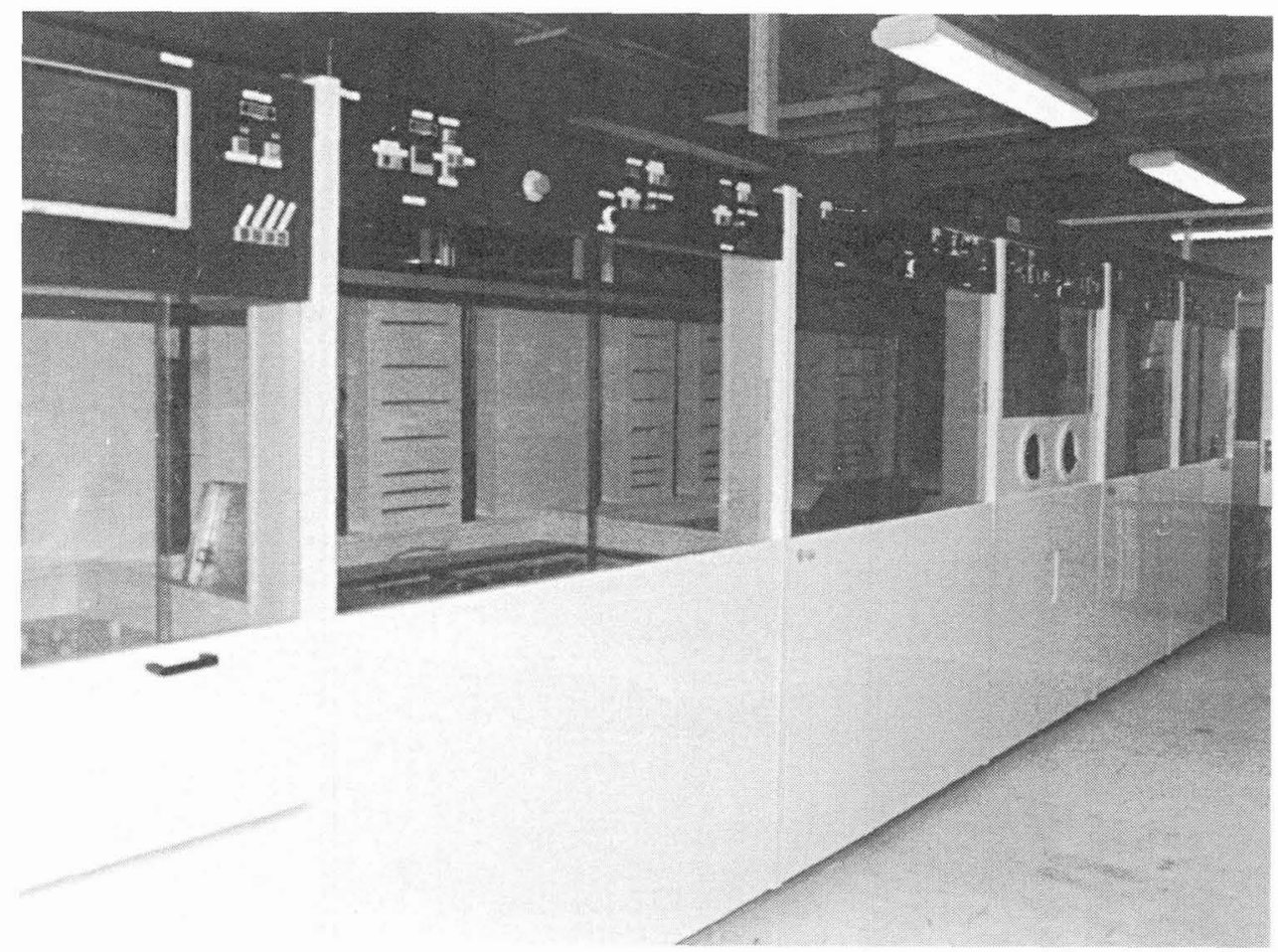

Figure 4: Industrial equipment of quartz chemical etching 